\title{
Description of the new freshwater diatom genus Okhapkinia gen. nov. from Laos (Southeast Asia), with notes on family Sellaphoraceae MERESCHKOwSKY 1902
}

\author{
Maxim KulikovskiY ${ }^{1,2 *}$, Anton Glushchenko ${ }^{1,3}$, Irina KuzNetsova ${ }^{1} \&$ John Patrick \\ KOCIOLEK $^{4,5}$
}

\author{
${ }^{1}$ Papanin's Institute for Biology of Inland Waters Russian Academy of Sciences, Russia, 152742 Yaroslavl, \\ Nekouz, Borok and ${ }^{2}$ Institute of Plant Physiology, Russian Academy of Sciences, Botanical Street 35, 127276, \\ Moscow, Russia; :Corresponding authore-mail: max-kulikovsky@yandex.ru \\ ${ }^{3}$ Kaluga State University, 248023, Kaluga District, Stepan Rasin Street 26, Kaluga, Russia \\ ${ }^{4}$ Museum of Natural History and ${ }^{5}$ Department of Ecology and Evolutionary Biology University of Colorado, \\ Boulder, Colorado, 80309 USA
}

\begin{abstract}
A new monotypic diatom genus from Laos is described, Okhapkinia alexandrii GLUSHCHENKO, KuLIKovsKIY et KocioleK gen. et sp. nov. The new genus is described on the basis light and scanning electron microscope observations. This genus is similar morphologically to the genus Sellaphora MereschKowsKy on the basis of several shared features. These features include presence of uniseriate striae, internal hymenate pore occlusions, large, elongate helictoglossae, round depressions at the valve face mantle junction, straight internal raphe slit, presence of longitudinal lines positioned on either side of the axial area, and striae arrangement and shape. The new genus is diagnosed by having an external, undulate raphe slit, absence of polar bars, presence of massive basal siliceous layer, and presence of rims and external thickenings around the areolae, central raphe ends curved to different sides internally and very prominent elongated hymenes internally. In all of these features the new genus differs from Sellaphora. The shared features between Okhapkinia gen. nov. and Sellaphora suggest the new genus should be assigned to the Sellaphoraceae MerESCHKOwSKY. Similarites between Okhapkinia gen. nov. and other newly-described genera are discussed. We consider the newly described genus Altana KULIKOvSKIY, LAnge-Bertalot et Metzeltin, which shares the feature of external silica outgrowths with Okhapkinia gen. nov. to be part of the family Cavinulaceae D.G. Mann. The genus Buryatia Kulikovskiy, LANGe-BerTalot et MetzeLtin described from Lake Baikal may represent another genus closely related to Sellaphora, and suggest it is also a member of the family Sellaphoraceae.
\end{abstract}

Key words: diatom, Laos, morphology, new genus, Okhapkinia, Sellaphoraceae, Southeast Asia

\section{INTRODUCTION}

Laos is part of Southeast Asia, a region that is relatively poorly studied in terms of its freshwater algal biodiversity and biogeography. With regard to freshwater diatoms, there were a few studies in the $19^{\text {th }}$ century that considered a small number of taxa (EHRENBERG 1854; GRUNOw 1865; MÜLler 1890; LeUduger-ForTMORel 1892; Cleve 1894), and the $20^{\text {th }}$ century also did not yield a large number of studies or endemic species (ØSTRUP 1902; MeISTER 1932; Hustedt 1937-1938; Prowse 1962; Skvortzow 1930, 1932, 1946; Amossé 1969; Hirano 1967; VoIGT 1969; FoGED 1971, 1976; OHNO et al. 1972). In the $21^{\text {st }}$ century, application of water quality monitoring led to more reports on the freshwater diatoms of the region (e.g. DuONG et al. 2002; FuJita \& OHTSUKA 2005; OHTAKa et al. 2010; Leelahakriengkrai et al. 2009; Yana \& PeerapornPisal
2009; Suphan \& PeERAPORNPISAl 2009, 2010; BlanCo et al. 2012), but did not yield description of novel or endemic species. Recently new species and some taxonomical reinvestigation including morphology of some rare species have been described from Vietnam, Laos and Indonesia in our publications (GUSEv \& KULIKOVSKIY 2014; GLushCHENKo \& KULIKOvSKIY 2017; KocioleK et al. 2015; KulikovsKiY et al. 2015a; GLushCHENKo et al. 2016; Kapustin et al. 2017).

According to Round et al. (1990) the family Sellaphoraceae MereschKowKY includes genera such as Sellaphora Mereschrowsky, Fallacia Stickle et D.G. MAnn, Rossia Voigt and Caponea PoDzorski. The last two genera are marine taxa however, while taxa from two firstly mentioned genera may inhabit marine or freshwater environments. Sellaphora and Fallacia are similar in plastid morphology and movements and the 
presence of conopeum occurs in Fallacia and may be present in Sellaphora. In both genera areolae are uniseriate and covered by internal hymenate occlusions (Round et al. 1990). For nearly 3 decades, since the publication of Round et al. (1990) many new diatom genera have not been assigned to any families. Good examples of this are genera describing in Iconographia Diatomologica or Bibliotheca Diatomologica volumes (see KULIKovsKIY et al. 2010b, 2012b, 2015b; MetZELTIN et al. 2009 and others) or independent peer-review journals (see CANTONATI et al. 2009 and many others). Cox (2015) has attempted to rectify this situation.

KocIOLEK et al. (2013b) studied enigmatic cavedwelling diatom Diprora MAIN from Hawaii. Due to its lack of a raphe system and bilateral symmetry, the genus was first assigned to the araphid diatoms (MAIN 2003), but its systematic affinities were undetermined. A three-gene phylogeny, based on nuclear (SSU rDNA) and chloroplast ( $r b c \mathrm{~L}, p s b \mathrm{C}$ ) genes, was develop to ascertain the phylogenetic relationships of this enigmatic, cavedwelling diatom. Their analysis showed this diatom to be most closely allied with taxa referred currently to the Sellaphoraceae, including Sellaphora and Fallacia. They suggested that loss of the raphe system and reduction of other features may be related to its cave-dwelling habit. However, Diprora is characterized by the presence of hymenes and a single $\mathrm{H}$-shaped chloroplast lying against the epivalve.

Liv et al. (2012) described a new genus Pseudofallacia Y. LIU, KocioleK et Q.X. WANG that is morphologically closely related to Fallacia. Pseudofallacia as a genus characterized by presence of two longitudinal depressions along the narrow sternum are covered externally by a perforated conopeum along the raphe, and with two pores at each terminal area. The striae are distinctive; are interrupted by the conopeum at the axial area, and have one large areola per stria, which was closed on the valve exterior. LiU et al. (2012) also showed the similarity between chloroplast morphology of Sellaphora, Fallacia and Pseudofallacia but they did not formally assign the newly described genus to the Sellaphoraceae.

Later on, Tudesque et al. (2015) described new genus Lacuneolimna Tudesque, Le CoHU \& LANGEBerTALOT from French Guiana. These authors put their new genus in the family Sellaphoraceae on the basis raphe morphology and presence of elevated hymenes internally. This genus differs from Sellaphora and Fallacia by the multiseriate striae with three or four lines of areolae. In their discussion, TUDESQUE et al. (2015) compared the new genus with the previously described genus Eolimna that is characterized by biseriate or uniseriate striae composed of large areolae covered by medially-placed hymenes in the areola, as proposed by SCHILLER and LANGE-BERTALOT (1997; see also Moser et al. 1998; KULIKOvSKIY et al. 2010, 2012a, 2015c). Moser et al. (1998) placed this genus in the family Naviculaceae sensu SimONSEN (1979). However, some do not recognize Eolimna as a distinct genus, and almost all species from this genus were transferred to the genus Sellaphora (Wetzel et al. 2015).

Molecular data used for phylogeny reconstruction of the family Sellaphoraceae are not extensive. The genus Sellaphora is the most studied genus of the family from a molecular point of view, including the comprehensive work of D.G. MANN and coauthors (MANN et al. 1999, 2003, 2004; Evans et al. 2008). Phylogenetic positions of Fallacia pygmaea (Kützing) Stickle \& D.G. MAnN and Pseudofallacia monoculata (HuSTEDT) Y. LiU, KocIOLEK et WANG (in molecular tree shown as Fallacia monoculata (HustedT) D.G. MANN) were shown recently (KocIOLEK et al. 2013b; KuLIKOvSKIY et al. 2014a). These analyses indicated that two taxa are closely related and are part of one clade, but without any statistical support. The genus Rossia is closely related to Fallacia and Sellaphora branches (KocIOLEK et al. 2013b) as also observed by Mann \& Stickle (2009). Molecular investigation of Eolimna minima (GRUNOW) LANGE-BERTALOT showed that this species is combined in phylogenetic tree with other species of Sellaphora (KULIKOVSKIY et al. 2014a). Investigation of type material by WETzEL et al. (2015) showed that current name of this taxon must be, according to the International Code of Botanical Nomenclature, Sellaphora nigri (De Notaris) Wetzel \& Ector. So, there is currently very limited taxon sampling among groups within the Sellaphoraceae. We need more strains and taxa to be included in molecular analyses to achieve a better understanding of the taxon relationships within the Sellaphoraceae.

The aim of this work is to describe a new monospecific diatom genus from Laos and to offer a discussion of its systematic position. This work continues our investigation of diatoms from Southeast Asia, at the genus and species levels. Additionally, we discuss morphology and phylogenetic position of some genera that were described after Round et al. (1990) and argue for their placement in the family, and discuss their relationships within the Sellaphoraceae.

\section{Material ANd Methods}

Studied sample was collected from Laos by E.L. KonstANTINOV in 06.12.2014: № 01612 - Nam Hinboun River near Kong Lor Cave, Vientiane province, Laos, $17^{\circ} 53.783^{\prime} \mathrm{N}, 104^{\circ} 45.667^{\prime}$ E. Water temperature was about $20^{\circ} \mathrm{C}$ and conductivity 111 $\mu \mathrm{S} . \mathrm{cm}^{-1}$ in studied places. Water mineralization and temperature measurements were performed using the Hanna Combo (HI 98129) device, Hanna Instruments, Inc., USA.

Samples for light microscopy (LM) and scanning electron microscopy (SEM) investigations were processed by means of a standard procedure involving treatment with $10 \%$ $\mathrm{HCl}$ and concentrated hydrogen peroxide. After treatment, the sample was washed with deionized water. Permanent diatom preparations have been mounted in Naphrax ${ }^{\circledR}$. LM observations were performed by means of a Zeiss Axioscope A1 microscope equipped with oil immersion objective $(\times 100 /$ n.a.1.4, DIC). Valve ultrastructure was examined with a JSM-6510LV field emission scanning electron microscope (Borok, Russia). 


\section{ReSUltS}

Okhapkinia alexandrii GLUSHCHENKo, KULIKOVSKIY et KocioleK gen. et sp. nov. (Figs 1-20)

Description: With light microscopy (Figs 1-8), valves appear elliptical with cuneate-obtuse ends. Length 44-70 $\mu \mathrm{m}$, breadth 18-24 $\mu \mathrm{m}$. Axial area straight, broadening slightly at the center to form a more or less linear central area. Raphe distinctly undulate, lateral, with proximal raphe ends dilated and distinct, curved to one side of the valve. External distal raphe ends deflected onto the mantle and to the side opposite the proximal ends. Striae radiate, strongly so at the apices, 13-14 in $10 \mu \mathrm{m}$. Striae composed of large, rectangular openings, until reaching the axial area, and then elongate openings with smaller areolae. Longitudinal lines are positioned on either side of the axial area, expanded at the center of the valve.

SEM, exterior valve view (Figs 9-14), the valve face with wide openings, part of a siliceous covering over the basal siliceous layer. Individual openings through this outer cover are ovoid to nearly rectangular and through each two areolae are visible. Individual areolar openings have a narrow rim, and can be separated by a thickening (Figs 9-11). At the apices, and at the center, the outer openings are more elongate, and reveal several to many areolae in uniseriate rows (Figs 10, 12, 14). A narrow depression borders the axial area (Fig. 10). A mottled covering may exist over the trough near the center of the valve (Fig. 10).

Internal valve views with SEM show the linear-lanceolate axial area is evident (Figs 15, 16). Proximal raphe ends are not aligned and turned slightly in opposite directions (Fig. 16). Each stria is occluded with single to double rows of hymenate occlusions (Figs 16-20). At the apices, elongate helictoglossae are evident. A round depression is positioned beyond the helictoglossa at the valve mantle junction at each end of the valve (Figs 19, 20).

Etymology: species and genus dedicated to Russian hydrobiologist and algologist Prof. Dr. ALEXANDER OKHAPKIN from Nizniy Novgorod University.

Type locality: Laos, Nam Hinboun River, sample 01612 $\left(17^{\circ} 53.783^{\prime} \mathrm{N}, 104^{\circ} 45.667^{\prime} \mathrm{E}\right)$, leg. E.L. Konstantinov, coll. date 06.12 .2014

Holotype (designated here): №01612 (IBIW, Russia).

\section{Discussion}

Okhapkinia alexandrii is similar to the genus Sellaphora on the basis of features observed with LM. These two genera are similar by having elliptical valves, similar areolar structure and presence of longitudinal lines positioned on either side of the axial area, expanded at the center of the valve. But these two genera are very distinct from one another by the presence of undulate raphe situated on very wide external sternum without conopeum in Okhapkinia gen. nov. (MANN 1989; Round et al. 1990; MANN 2001; KULIKOVSKIY et al. 2010b; LEVKOV et al. 2006, 2007; JAHN et al. 2008; MANN et al. 2008, 2009). There is variability in terms of features shared by members of the genus Sellaphora. D.G. MANN et al. (2008) divided Sellaphora into five provisional morphological groups that are distinguishable in LM, including "americana", "laevissima", "seminulum", "bacillum" and "pupula" groups. Species from the "americana" group differ by the presence of a wide axial area and distinct central nodule, features that are absent in Okhapkinia gen. nov. The three groups, "laevissima", "bacillum" and "pupula" are characterized by the presence of polar bars and faculatatively possessing a conopeum and conopeal grooves present alongside the raphe, features that are also absent in Okhapkinia gen. nov. Species of the "laevissima" group share with Okhapkinia gen. nov. the presence of longitudinal lines (or "grooves" in terminology of MANN et al. 2008) alongside the raphe. However, in species of the "laevissima" group these longitudinal lines are very narrow but in Okhapkinia gen. nov. the longitudinal lines are very broad. Species of the "seminulum" group are small-celled representatives of the genus Sellaphora and many of them considered belonging to the genus Eolimna sensu Lange-Bertalot (Wetzel et al. 2015).

Differences between Sellaphora and Okhapkinia gen. nov. are more evident in the SEM. The undulate raphe is situated on very broad external raphe sternum, a feature that is not typical for Sellaphora taxa. Another difference between the two genera is the distinctive areolae structure and morphology of valve face in Okhapkinia gen. nov. Externally, the valve face of Okhapkinia gen. nov. has wide openings, part of a siliceous covering over the basal siliceous layer. Individual openings through this outer cover are ovoid to nearly rectangular and through each two areolae are visible. This massive external layering of silica is unknown in the species groups of Sellaphora described by MANN et al. (2009), and described for other known species of the genus (LEVKov et al., 2006, 2007, MANN et al. 2009 and others). However, species with a similar siliceous layer were shown and described by us from Lake Baikal (KULIKovSKIY et al. 2012b; pl. 96: 1-6, pl. 97: 1-6, pl. 98: 1, 2, P1. 99: 1-3, pl. 100: 1-5). These include Sellaphora amicula KulikovskiY, Metzeltin et Lange-Bertalot, $S$. pseudamicula Metzeltin, Kulikovskiy et LANGe-Bertalot and $S$. ovalis Kulikovskiy, Metzeltin et Lange-Bertalot. The thick siliceous layer in these species is not as massive as in Okhapkinia gen. nov. and many areola perforations are open. Metzeltin and LANGE-BERTALOt (1998) studied morphology of Sellaphora lambda (Cleve) Metzeltin et LANGE-BERTALOT, another large-celled taxon known from South America. This species is characterized by 

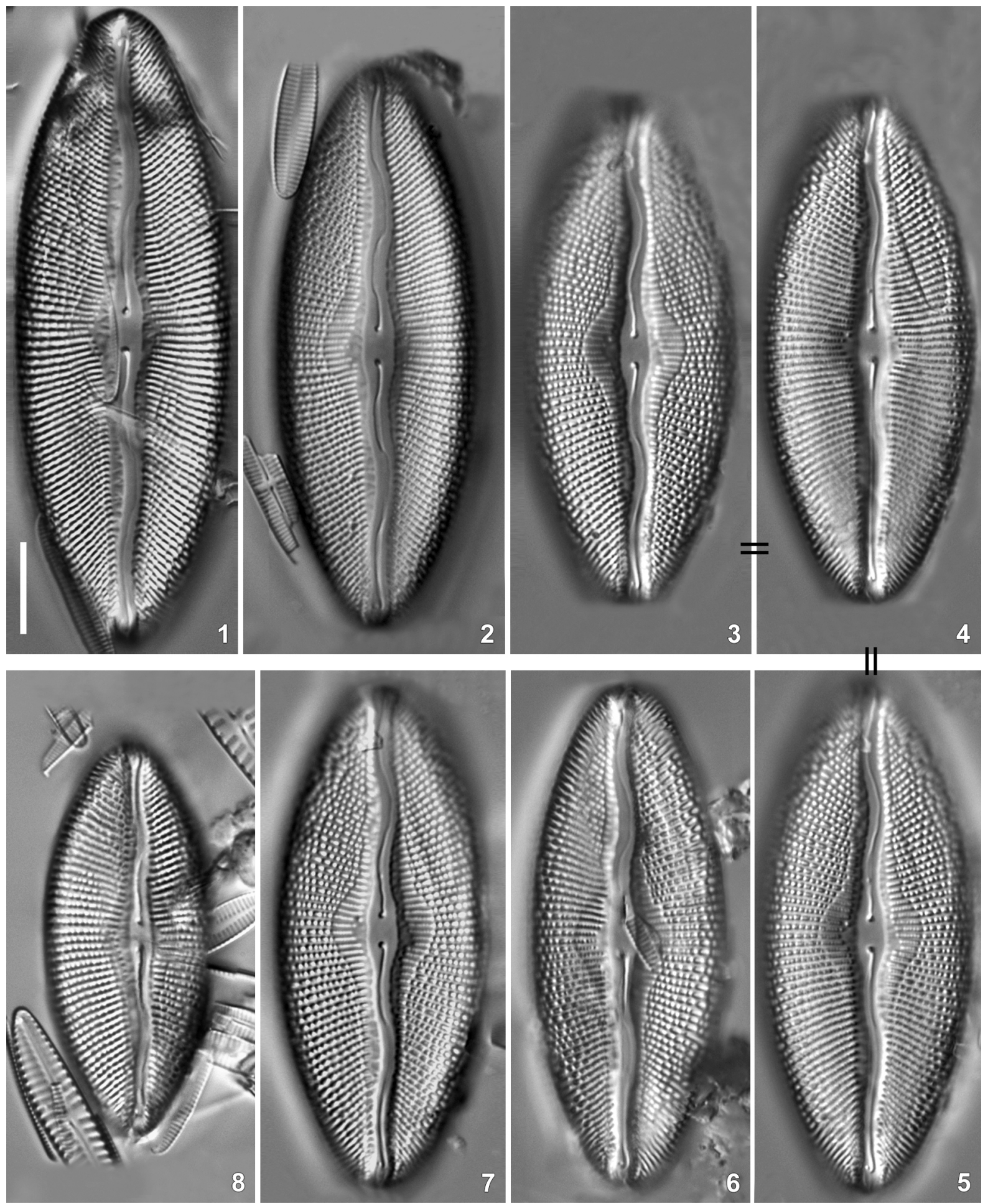

Figs 1-8. Okhapkinia alexandrii, gen. et sp. nov., LM, size diminution series, valve views, (2) holotype. Scale bar $10 \mu \mathrm{m}$.

the presence of a thick siliceous external layer. Round areolae are embedded into this silica layer and one or four of them opened by ovoid openings and through each areolae are visible (MetZeltin \& LANGe-BerTalot 1998; pl. 84: 3). However, all other morphological features of S. lambda are typical of that genus such as uniseriate striae, straight raphe, typical hymenate occlusions inside, striae arrangement and other.
The external areolar structure of Okhapkinia gen. nov. is more complex than in Sellaphora amicula, S. pseudamicula, S. ovalis and S. lambda. Individual areolar openings in Okhapkinia gen. nov. have a narrow rim, and a thickening can separate areolae. Presence of these rims (crater-like structure) and thickenings are unknown for Sellaphora species (MANN 1989; Round et al. 1990; KuLikovskiY et al. 2010b; MetzeLtin et al. 2005, 2009; 

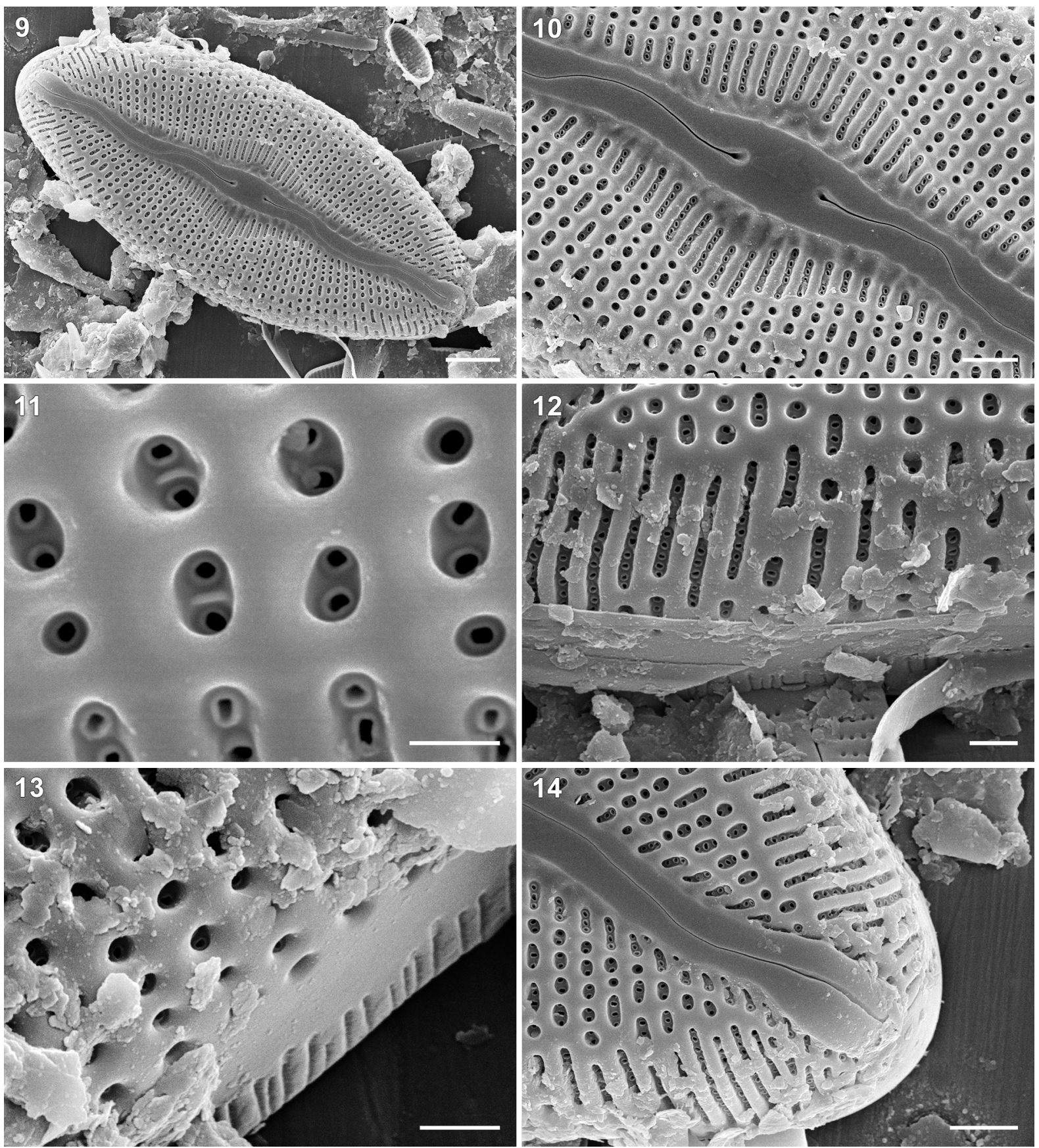

Figs 9-14. Okhapkinia alexandrii, gen. et sp. nov., SEM, external views: (9) Whole valve view, showing elliptical valve with distinct axial area with undulate raphe. Longitudinal lines run the length of the valve on either side of the axial area. (10) Central area, with dilated proximal raphe ends, elongated openings with uniseriate rows of smaller opening positioned internally to them. The axial area is thickened and slightly raised. Striae appear as large, uniseriate rows of openings. (11) Structure of the striae with larger external openings within which are 2 openings of the areolae. Each areolar opening is bordered by a thickened rim. (12) Elongated striae openings with several areolae in uniseriate rows are evident. (13) Valve mantle with unornamented hyaline area with irregularly-placed slits. (14) Terminus of the valve, showing undulate raphe branch on wide axial area, silica layer with wide openings overtop rows of areolae with thickend silica rims. Scale bar $5 \mu \mathrm{m}(9), 2 \mu \mathrm{m}(10$, 14), $1 \mu \mathrm{m}(12,13), 0.5 \mu \mathrm{m}(11)$.

MetZeltin \& LANGe-BerTaLOT 1998, 2007). The presence of similar crater-like structure in the genera Skvortzowia KulikovsKiy, Lange-Bertalot et MetZeLtin and Khursevichia Kulikovskiy, LANGE-Bertalot et Metzeltin from Lake Baikal was documented previously (KuLIKovsKIY et al. 2012b). The genus Khursevichia belongs to the family Cymbellaceae GrevILLE, while Skvortzowia is possibly close to the family Stauroneidaceae D.G. MANN (KULIKOVSKIY \& KUZNETSOVA 2016). Therefore, it appears that this structure arose several times in different phylogenetic groups of naviculoid and cymbelloid diatoms.

Striae in Okhapkinia gen. nov., like those in Sellaphora, extend from the valve face to the mantle, however there is present a wide hyaline area in former 

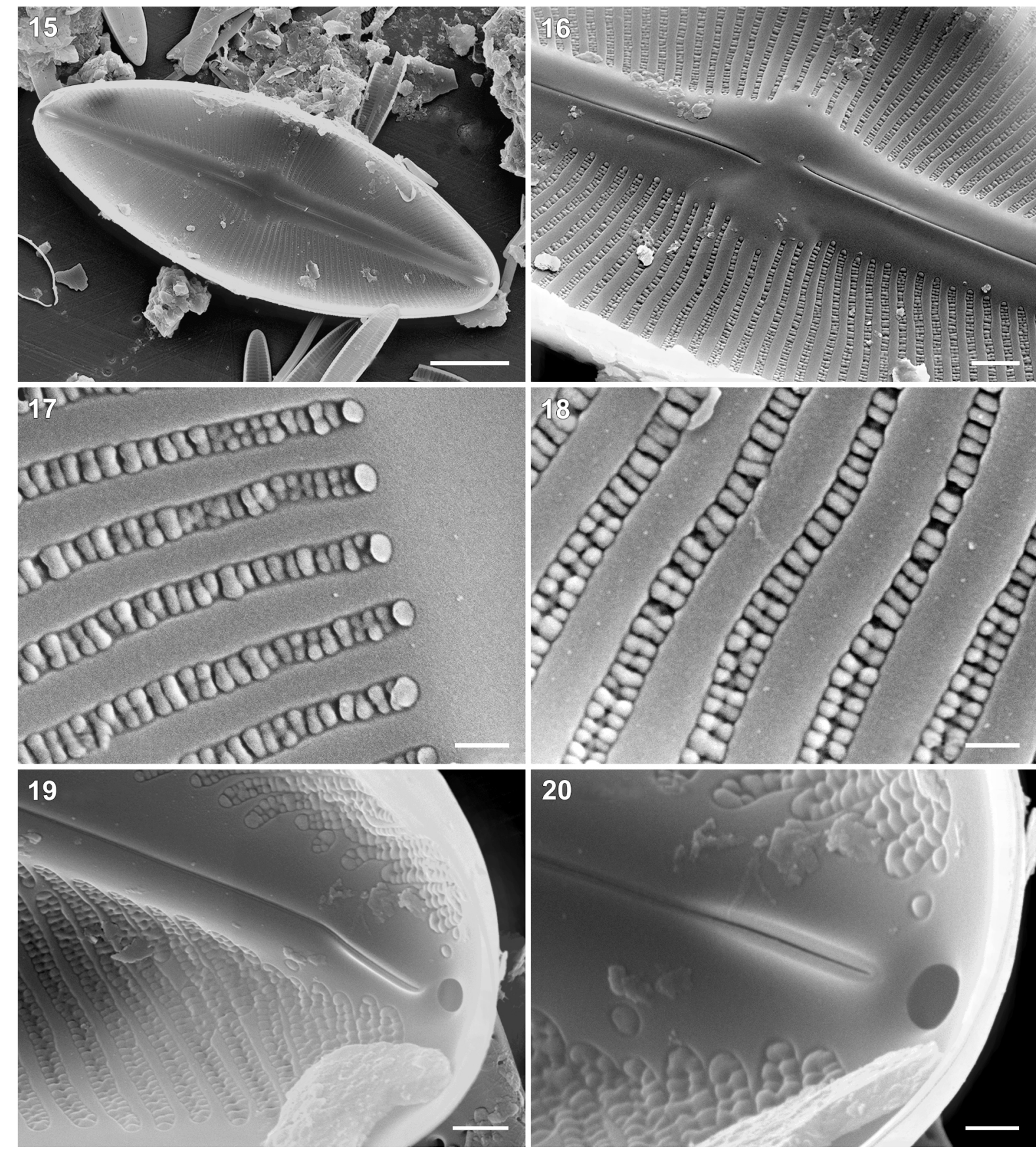

Figs 15-20. Okhapkinia alexandrii, gen. et sp. nov., SEM, internal views: (15) Whole valve view, with raphe sternum evident as well as distinct helictoglossae at the poles. (16) Central area, showing proximal raphe ends deflected slightly in opposite directions. $(17,18)$ Striae with many small occlusions arranged in uniseriate or biseriate rows. The occlusion near the axial area is single and larger than the others. $(19,20)$ Valve apex, with large, elongated helictoglossa, striae with the numerous occlusions and round depression present beyond the helictoglossa towards the valve mantle. Scale bar $10 \mu \mathrm{m}(15), 2 \mu \mathrm{m}(16), 1 \mu \mathrm{m}(19), 0.5 \mu \mathrm{m}(17,18,20)$.

genus. The mantle has a wide hyaline band, the edge of which has a row of elongated, irregularly spaced slits. This type of mantle structure is unknown for Sellaphora (MANn 1989; KuLIKOVSKIY et al. 2012b, and etc.).

Internally, Okhapkinia gen. nov. differs from Sellaphora by having proximal raphe ends that are deflected to different directions. Central raphe ends in Sellaphora always turned to the same (primary) side (MANN 1989; Round et al. 1990). Pore occlusions of Okhapkinia gen. nov. are positioned internally as in the genus Sellaphora. Sellaphora has small, circle- to dome-shaped hymenes covering the areolae internally (Round et al. 1990). The genus Okhapkinia gen. nov. is characterized by the presence of very prominent, elongated hymenes inside. This feature also differentiates the new genus from Sellaphora. Okhapkinia gen. nov. and Sellaphora share internal morphological features such as presence of wide raphe sternum, large, elongated helictoglossae, and a round depression positioned beyond the helictoglossa on the valve mantle. 
Assignment of the new genus to the Sellaphoraceae, and thus having a close relationship with Sellaphora, is based on a number of shared features. These are: uniseriate striae, hymenate pore occlusion internal, large, elongate helictoglossae, round depressions at the valve mantle internally, straight raphe internally, presence of longitudinal lines positioned on either side of the axial area, striae arrangement and shape. Such features as undulate raphe externally, absence of polar bars, presence of massive siliceous layering externally, presence of rims and thickening in areolae externally, internal proximal raphe ends curved to different sides, and very prominent elongated hymenes internally distinguish the new described genus from Sellaphora.

The genus Okhapkinia gen. nov. appears similar to the genus Altana KulikovskiY, LANGE-BerTALOT et Metzeltin that was described from Lake Baikal (KuLIKovskiY et al. 2012b). The genus Altana is known as an endemic taxon for Baikal and from fossil sediments for the Transbaikal area (KuLIKOvsKIY et al. 2012b). This genus is characterized by the very thick massive valves that are covered externally with siliceous outgrowths. The genus Altana is close to the genus Cavinula D.G. MANN \& STICKLE, based on the presence of external distal raphe ends turned to different sides on the valve face, internal areolae covered by hymenes, which cover each stria entirely (Round et al. 1990; KULIKOvSKIY et al. 2012b). The genus Altana was not originally assigned to any family, but it should be considered in the family Cavinulaceae D.G. MANN.

Presence of massive siliceous layer might be considered as a process of extra silicification of valves that is similar to the presence of different kinds of outgrowths on the valves in other diatoms. These siliceous outgrowths and additional silica layers internally were shown for Sellaphora, Altana, Lacuneolimna, Geissleria LANGE-Bertalot et Metzeltin, Placoneis Mereschkowsky, Navicula Bory, Amphora Ehrenberg, Eunotia EHrenberg and Celebesia Kapustin, KulikovskiY et Kociolek (Metzeltin \& LANGe-Bertalot 1998, 2007; Moser et al. 1998; Metzeltin et al. 2005; KAPUSTIN et al. 2017). The last-mentioned genus, which belongs to the lineage of freshwater cymbelloid diatoms, was described from ancient Lake Matano in Indonesia. Valves of Celebesia from different developmental stages had different completeness of the basal siliceous layer (KAPUSTIN et al. 2017). So, the basal siliceous layer and outgrowths arose many times in different phylogenetic lineages of diatoms. It is interesting to point out that these kinds of morphological peculiarities are often found in taxa inhabiting the tropics, ancient lakes (of which Lake Baikal is most studied; KULIKovsKiY et al. 2012a,b, 2013, 2014a,b, 2015b,c, 2016; KocIOLEK et al. 2013; KulikovSKiY \& KuZNETSOVA 2016; VishnYAKOV et al. 2014, 2015; KocioLEK et al. 2017) or oligotrophic lakes with high silica content (see THERIOT 1987 relative to the genus Stephanodiscus EHRENBERG).

Another genus that was previously described from Lake
Baikal is Buryatia KulikovsKiY, LANGE-BerTALOT et Metzeltin (KuliKovsKIY et al. 2012b). This genus is characterized by having broadly elliptical or linear valves with obtusely to broadly rounded apices. Valve faces are flat, curving rather abruptly into shallow mantles. The raphe system has nearly straight to slightly curved external branches, proximal ends barely or weakly deflected into small central pores, distal raphe ends prolonged or curving onto the mantle, both in the same direction. Presence of hymenes in middle portion of areolae is similar to many species of Eolimna as described originally by SCHILLER and LANGE-BERTALOT (1997) and many of these species have been transferred to the genus Sellaphora (WETZEL et al. 2015). Buryatia and Sellaphora are similar in the presence of a wide raphe sternum internally, straight raphe, proximal raphe ends that are turned to the same side internally. We suggest this genus should be included in the family Sellaphoraceae.

The family Sellaphoraceae are including following genera: Sellaphora, Fallacia, Rossia, Caponea, Okhapkinia, Buryatia, Pseudofallacia, Lacuneolimna, Eolimna and Diprora according to our and published data.

\section{ACKNOWLEDGEMENTS}

The publication is based on research carried out with financial support provided by the Russian Science Foundation (14-14-00555).

\section{REFERENCES}

Cantonati, M.; Van de Vijver, B. \& Lange-Bertalot, H. (2009): Microfissurata gen. nov. (Bacillariophyta), a new diatom genus from dystrophic and intermittently wet terrestrial habitats. - Journal of Phycology 45: $732-741$.

Cleve, P.T. (1894): Synopsis of the naviculoid diatoms. Part 1. Kongliga Svenska. -Vetenskaps Akademiens Handlingar 26: 1-194.

Cox, E.J. (2015): Coscinodiscophyceae, Mediophyceae, Fragilariophyceae, Bacillariophyceae (Diatoms). - In: JAKLITSCH, W.; BARAL, H.O.; LÜCKING, R.; LUMBSCH, H.T. \& FreY, W. (eds): Syllabus of Plant Families. Adolf Engler's Syllabus der Pflanzenfamilien. Part 2/1. Photoautotrophic eukaryotic Algae: Glaucocystophyta, Cryptophyta, Dinophyta/Dinozoa, Haptophyta, Heterokontophyta/ Ochrophyta, Chlorarachniophyta/Cercozoa, Euglenophyta/ Euglenozoa, Chlorophyta, Streptophyta. - pp. 64-103, Borntraeger Verlagsbuchhandlung, Stuttgart.

Duong, T.T.; Coste, M.; Feurtet-Mazel, A.; DAng, D.K.; Gold, C.; PARK, Y.S. \& Boudou, A. (2002): Impact of urban pollution from the Hanoi area on benthic diatom communities collected from the Red, Nhue and Tolich rivers (Vietnam). - Hydrobiologia 563: 201-216.

EhrenberG, C.G. (1854): Mikrogeologie. Das Erden und Felsen schaffende Wirken des unsichtbar kleinen selbstständigen Lebens auf der Erde. Text and Atlas. - 374 pp., Leopold Voss, Leipzig.

Evans, K.M.; Wortley, A.H.; Simpson, G.E.; Chepurnov, V.A. \& MANN, D.G. (2008): A molecular systematic approach to explore diversity within the Sellaphora pupula species complex (Bacillariophyta). - Journal 
of Phycology 44: 215-231.

Foged, N. (1971): Freshwater diatoms in Thailand. - Nova Hedwigia 22: 267-369.

Foged, N. (1976): Freshwater diatoms in Sri Lanka (Ceylon). - Bibliotheca Phycologica 23: 1-112.

Fujita, Y. \& OHTsuka, T. (2005): Diatoms from paddy fields in Northern Laos. - Diatom 21: 71-89.

Glushchenko, A.M. \& Kulikovskiy, M.S. (2017a): Amphipleura vavilovii: a new diatom species of the family Amphipleuraceae from Laos. - Inland Water Biology 10: 17-21.

GlushChenko, A.M.; GenKal, S.I. \& Kulikovskiy, M.S. (2016): Aulacoseira konstantinovii sp. nov. and Aulacoseira krylovii sp. nov. - two new centric diatoms from South-east Asia. - Diatom Research 31: 367-378.

Grunow, A. (1865): Über die von Herrn Gerstenberger in Rabenhorst's Decaden ausgegeben Süsswasser Diatomaceen und Desmidiaceen von der Insel Banka, nebst Untersuchungen über die Gattungen Ceratoneis und Frustulia. - Beiträge zur näheren Kenntniss und Verbreitung der Algen 2: 1-16.

Gusev, E.S. \& KulikovskiY, M.S. (2014): Centric diatoms from Vietnam reservoirs with description of one new Urosolenia species. - Nova Hedwigia, Beiheft 143: $111-126$.

Hirano, H. (1967): Freshwater algae collected by the joint Thai-Japanese biological expedition to Southeast Asia 1961-62. - Nature and Life in Southeast Asia 5: 1-71.

HustedT, F. (1937-1938): Systematische und ökologische Untersuchungen über die Diatomeen-Flora von Java, Bali und Sumatra nach dem Material der Deutschen Limnologischen Sunda-Expedition. - Archiv für Hydrobiologie Supplement 15: 131-506.

Jahn, R.; Mann, D.G.; Evans, K.M. \& PoulíčKová, A. (2008): The identity of Sellaphora bacillum (Ehrenberg) D.G. Mann. - Fottea 8: 121-124.

KaPustin, D.A.; KulikovskiY, M.S. \& KocioleK, J.P. (2017): Celebesia gen. nov., a new cymbelloid diatom genus from the ancient Lake Matano (Sulawesi Island, Indonesia). - Nova Hedwigia, Beiheft 146: 147-155.

Kociolek, J.P.; Glushchenko, A.M. \& Kulikovskiy, M.S. (2015): Typification, valve ultrastructure, and systematic position of Gomphonema gomphopleuroides Amossé ex Kociolek, Glushchenko \& Kulikovskiy, an endemic diatom from Southeast Asia. - Diatom Research 30: 247-255.

Kociolek, J.P.; HAMSher, S.E.; Kulikovskiy, M.S. \& Bramburger, A.S. (2017): Are there species flocks in freshwater diatoms? A review of past reports and a look to the future. - Hydrobiologia 792: 17-35.

KocioleK, J.P.; Kulikovskiy, M.S. \& SolaK, C.N. (2013a): The diatom genus Gomphoneis Cleve (Bacillariophyceae) from Lake Baikal, Russia. - Phytotaxa 154: 1-37.

Kociolek, J.P.; StePaneK, J.G.; Lowe, R.L.; Johansen, J.R. \& SHERwoOd, A.R. (2013b): Molecular data show the enigmatic cave-dwelling diatom Diprora (Bacillariophyceae) to be a raphid diatom. - European Journal of Phycology 48: 474-484.

Kulikovskiy, M.S.; Glushchenko, A.M.; \& Kociolek, J.P. (2015a): The diatom genus Oricymba in Vietnam and Laos with description of one new species, and a consideration of its systematic placement. - Phytotaxa 227: 120-134.

Kulikovskiy, M.S.; Gusev, E.; ANDREeva, S.A. \& AnNenKova, N.V. (2014a): Phylogenetic position of the diatom genus Geissleria Lange-Bertalot \& Metzeltin and description of two new species from Siberian mountain lakes. - Phytotaxa 177: 249-260.

Kulikovskiy, M.S. \& KuZnetsova, I.V. (2016): Morphology, taxonomical position, and distribution of the genera of diatoms Ochigma and Khursevichia from Lake Baikal. - Inland Water Biology 9: 226-233.

Kulikovskiy, M.S.; LANGe-Bertalot, H.; Khursevich, G.K. \& KuZNETSOVA, I.V. (2012a): New diatom species of the genus Eolimna (Bacillariophyceae) from Lake Baikal [in Russian]. - Novosti sist. nizh. rast. 46: 46-51.

Kulikovskiy, M.S.; LANGe-Bertalot, H. \& KuZnetsova, I.V. (2015c): Lake Baikal: hotspot of endemic diatoms II. - In: LANGE-Bertalot, H. (ed.): Iconographia Diatomologica. Annotated Diatom Micrographs, Vol. 26. - 657 pp., Koeltz Scientific Books, Oberreifenberg.

Kulikovskiy, M.S.; Lange-Bertalot, H.; KuZnetsova, I.V. \& KHURSEVICH G.K. (2015d): Three new species of Eolimna Lange-Bertalot \& Schiller (Bacillariophyta) from Lake Baikal. - Nova Hedwigia, Beiheft 144: 199-209.

Kulikovskiy, M.S.; Lange-Bertalot, H. \& Witkowski, A. (2010a): Diatom flora of Polistovo-Lowatsky sphagnum tract (European Russia). I. Eolimna chistiakovae sp. nov. and further transfers to the genus Eolimna LangeBertalot \& Schiller. - Diatom Research 25: 77-85.

Kulikovskiy, M.S.; Lange-Bertalot, H.; Metzeltin, D. \& WiтKOwsKi, A. (2012b): Lake Baikal: hotspot of endemic diatoms I. - In: LANGE-BERTALOT, H. (ed.): Iconographia Diatomologica. Annotated Diatom Micrographs, Vol. 23. -608 pp., A.R.G. Gantner Verlag K.G. Ruggell.

Kulikovskiy, M.S.; Lange-Bertalot, H. \& Witkowski, A. (2013): Gliwiczia gen. nov., a new achananthoid diatom genus with description of four species new for science. - Phytotaxa 109: 1-16.

KulikovskiY, M.S.; LANGE-Bertalot, H.; WitKowski, A.; DorofeyuK, N.I. \& GeNKAL, S.I. (2010b): Diatom assemblages from Sphagnum bogs of the World. I. Nur bog in northern Mongolia. - In: LANGE-BERTALOT, H. \& KocioleK, J.P. (eds): Bibliotheca Diatomologica, Vol. 55. - 326 pp., J. Cramer, Berlin, Stuttgart.

Kulikovskiy, M.S.; LANGE-Bertalot, H.; WitKowski, A. \& KuZnetsova, I.V. (2014b): Description of four species belonging in Cavinula D.G. Mann \& Stickle from Lake Baikal with notes on family Cavinulaceae D.G. Mann in Round et al. 1990. - Nova Hedwigia 99: 487-499.

Leelahakriengkrai, P.; Pruetiworanan, S. \& Peerapornpisal, Y. (2009): Diversity of benthic diatoms and macroalgae and water quality in the Mekong River passing Chiang Rai Province, Thailand. - KKU Science Journal 37: 143-152.

Leuduger-Fortmorel, G. (1892): Diatomées de la Malaisie. Annales du Jardin Botanique de Buitenzorg 11: 1-60.

Levkov, Z.; Krstic, S.; Metzeltin, D. \& Nakov, T. (2007): Diatoms of lakes Prespa and Ohrid. About 500 taxa from ancient lake system. - In: LANGE-BERTALOT, H. (ed.): Iconographia Diatomologica. Annotated diatom micrographs. Biogeography-Ecology-Taxonomy, Vol. 16. - 611 pp., A.R.G. Gantner, Ruggell, Liechtenstein.

Levkov, Z.; Nakov, T. \& Metzeltin, D. (2006): New species and combination from the genus Sellaphora Mereschkowsky from Macedonia. - Diatom Research 21: 297-312.

Liu, Y.; KocioleK, J.P.; FAN, Y. \& Wang, Q. (2012): Pseudofallacia gen. nov., a new freshwater diatom (Bacillariophyceae) genus based on Navicula occulta Krasske. - Phycologia 51: $620-626$. 
MaIn, S.P. (2003): Diprora haenaensis gen. et sp. nov., a filamentous, pseudoaerial, araphid diatom from Kaua'i (Hawaiian Islands). - Diatom Research 18: 259-272.

Mann, D.G. (1989): The diatom genus Sellaphora: separation from Navicula. - British Phycological Journal 24: 1-20.

ManN, D.G. (2001): The systematics of the Sellaphora pupula complex: typification of $S$. pupula. - In: JAHN, R.; Kociolek, J.P.; WitKowski, A. \& COMPÈRe, P. (eds): Lange-Bertalot-Festchrift. Studies on diatoms, dedicated to Prof. Dr. Dr. h.c. Horst Lange-Bertalot on the occasion of his 65th birthday. - pp. 225-241, A.R.G. Gantner, Ruggell, Liechtenstein.

MAnN, D.G.; ChePurnov, V.A. \& Droop, S.J.M. (1999): Sexuality, incompatibility, size variation, and preferential polyandry in natural populations and clones of Sellaphora pupula (Bacillariophyceae). - J. Phycol. 35: 152-170.

Mann, D.G.; Chepurnov, V.A. \& Idei, M. (2003): Mating system, sexual reproduction and auxosporulation in the anomalous raphid diatom Eunotia (Bacillariophyta). - J. Phycol. 39: 1067-1084.

Mann, D.G.; Evans, K.M.; ChePuRnov, V.A. \& NAGAI, S. (2009): Morphology and formal description of Sellaphora bisexualis sp. nov. (Bacillariophyta). - Fottea 9: 199-209.

Mann, D.G.; McDonald, S.M.; BAYER, M.M.; Droop, S.J.M.; Chepurnov, V.A.; LoKe, R.E.; Ciobanu, A. \& Du Buf, J.M.H. (2004): Morphometric analysis, ultrastructure and mating data provide evidence for five new species of Sellaphora (Bacillariophyceae). - Phycologia 43: 459-482.

Mann, D.G. \& Stikle, A.S. (2009): Cytological characteristics of the Sellaphoraceae. - Acta Bot. Croat. 68: 239-250.

ManN, D.G.; Thomas, S.J. \& Evans, K.M. (2008): Revision of the diatom genus Sellaphora: a first account of the larger species in the British Isles. - Fottea 8: 15-78.

Meister, F. (1932): Kieselalgen aus Asien. - 56 pp., Verlag von Gebrüder Borntraeger, Berlin.

Metzeltin, D. \& Lange-Bertalot, H. (1998): Tropical diatoms of South America I: About 700 predominantly rarely known or new taxa representative of the neotropical flora. - In: LANGE-BERTALOT, H. (ed.): Iconographia Diatomologica. Annotated Diatom Micrographs, Vol. 5. - 696 pp., A.R.G. Gantner Verlag K.G., Ruggell.

Metzeltin, D. \& Lange-Bertalot, H. (2007): Tropical diatoms of South America II: Special remarks on biogeographic disjunction. - In: LANGE-BERTALOT, H. (ed.): Iconographia Diatomologica. Annotated Diatom Micrographs, Vol. 18. - 887 pp, A.R.G. Gantner Verlag K.G., Ruggell.

Metzeltin, D.; Lange-Bertalot, H. \& Garcia-Rodriguez, F. (2005): Diatoms of Uruguay. - In: LANGE-BERTALOT, H. (ed.): Iconographia Diatomologica. Annotated Diatom Micrographs, Vol. 15. - 737 pp., A.R.G. Gantner Verlag K.G., Ruggell.

Metzeltin, D.; Lange-Bertalot, H. \& Soninkhishig, N. (2009): Diatoms in Mongolia - In: LANGe-Bertalot, H. (ed.): Iconographia Diatomologica, Vol. 20. - 703 pp., A.R.G. Gantner Verlag K.G. Ruggell.

Moser, G.; Lange-Bertalot, H. \& MetZeltin, D. (1998): Insel der Endemiten. Geobotanisches Phanomen Neukaledonien (Island of Endemics: New Caledonia - a geobotanical phenomenon). - In: LANGE-Bertalot, H. \& KocioleK, J.P. (eds): Bibliotheca Diatomologica, Vol. 38: - 464 pp., J. Cramer, Berlin, Stuttgart.

MüLlER, O. (1890): Bacillariaceen aus Java. - Ber. Deutsch. Bot. Ges. 8: 318-331.

Ohno, M.; Fukushima, H. \& Kobayashi, T. (1972): Diatom flora of the Mekong water system, Cambodia. - Natural Science 20: 1-24.

Ohtaka, A.; Watanabe, R.; Im, S.; Chhay, R. \& Tsukawaki, S. (2010): Spatial and seasonal changes of net plankton and zoobenthos in Lake Tonle Sap, Cambodia. - Limnology 11: 85-94.

ØstruP, E. (1902): Freshwater diatoms. In Flora of Koh Chang. Part VII. Contributions to the knowledge of the Gulf of Siam. Preliminary Report on Botany, Results Danish Expedition to Siam (1899-1900). - Botanisk Tidsskrift 25: 28-41.

Prowse, G.A. (1962): Diatoms of Malayan freshwaters. Gardens Bulletin, Singapore 19: 1-104.

Round, F.E.; Crawford, R.M. \& Mann, D.G. (1990): The diatoms. Biology and morphology of the genera. -747 pp., Cambridge University Press, Cambridge.

Schiller, W. \& LANGe-Bertalot, H. (1997): Eolimna martinii n. gen., n. sp. (Bacillariophyceae) aus dem Unter-Oligozan von Sieblos/Rhon im Vergleich mit ahnlichen rezenten Taxa. - Paläontologische Zeitschrift 71: 163-172.

Simonsen, R. (1979): The diatom system: ideas on phylogeny. - Bacillaria 2: 9-71.

Skvortzow, B.V. (1930): Notes on Ceylon diatoms. I. - The Ceylon Journal of Science, Section A, Botany 11: 251-260.

Skvortzow, B.V. (1932): Notes on Ceylon diatoms. II. - The Ceylon Journal of Science, Section A, Botany 11: 333-338.

Skvortzow, B.V. (1946): Species novae et minus cognitae Algarum, Flagellatarum et Phycomicetarum Asiae, Africae, Ameriae et Japoniae nec non Ceylon anno 1931-1945, descripto et illustrato per tab. 1-18. Proceedings of the Harbin Society of Natural History and Ethnography. Botany. Harbin 2: 1-34.

Suphan, S. \& Peerapornpisal, Y. (2009): Scanning electron microscope of benthic diatoms in Mekong River and its tributaries, Thailand. - Journal of Microscopy Society of Thailand 23: 42-46.

Suphan, S. \& PeERAPORNPISAL, Y. (2010): Fifty three new record species of benthic diatoms from Mekong River and its tributaries in Thailand. - Chiang Mai Journal of Science 37: 326-343.

THERIOT, E.C. (1987): Principal component analysis and taxonomic interpretation of environmentally related variation in silicification in Stephanodiscus (Bacillariophyceae). - British Phycological Journal 22: 359-373.

Tudesque, L.; Le Cohu, R.; Coste, M. \& LANGe-Bertalot, H. (2015): Lacuneolimna gen. nov., Lacuneolimna zalokariae comb. nov. and Lacuneolimna novagallia spec. nov. (Bacillariophyceae) from the French Guiana diatom freshwater flora. - Phytotaxa 231: 19-30.

VishnYaKov, V.S.; KuliKovsKiy, M.S.; GenKal, S.I. \& KuZNETSOVA, I.V. (2015): Comparative morphological characteristic of diatoms of genus Hannaea Patrick of the two largest lakes of the Baikal rift zone with a description of the new species. - Inland Water Biology 8: 222-231.

Vishnyakov, V.S.; Kulikovskiy, M.S.; GenKal, S.I.; DorofEYUK, N.I.; LANGE-Bertalot, H. \& KuZNETSOVA, I.V. (2014): Taxonomy and geographical distribution of the diatom genus Epithemia Kützing in water bodies of Central Asia. - Inland Water Biology 7: 318-330.

Voigt, M. (1969): Quelques diatomées du sud-est asiatique de distribution géographie limitée. - Revue Algologique, Nouvelle Série 9: 291-293.

Wetzel, C.E.; Ector, L.; VAn DE Vijver, B.; Compère, P. \& 
MANN, D.G. (2015): Morphology, typification and critical analysis of some ecologically important small naviculoid species (Bacillariophyta). - Fottea 15: 203-234.

Yana, E. \& PeErapornpisal, Y. (2009): Diversity of benthic algae and water quality in tributaries of the Mekong river passing Thailand and some parts of Lao PDR. -KKU Science Journal 37: 30-41.

(C) Czech Phycological Society (2018)

Received February 28, 2017

Accepted August 24, 2017 